\title{
MEMAHAMI BUDAYA KAUM MUDA \\ SEBUAH MISIOLOGI BARU DI JAGAD MAYA
}

Oleh: Darmanto ${ }^{1}$

\begin{abstract}
Abstact
The young generation is a very dynamic and unique, especially at the present time in which young people are connected to each other in ways that are unprecedented in previous generations. Advances in technology, particularly the internet and social media, changing times, increases creativity, patterns and relationships in the midst of a growing youth, encourage the creation of a culture of young people with different cultural communities that common. The Church will be missed and lost opportunities if it can't recognize and understand youth culture; so the Church needs to be entered in the community of young people so that young people can serve contextually, according to the truth of God's Word and right on target, so that young people have a spirituality which is good.
\end{abstract}

Key Words: Culture, young people, community, spirituality.

\begin{abstract}
Abstrak
Generasi muda adalah sangat dinamis dan unik, terutama pada masa sekarang di mana kaum muda terhubung satu sama lain dengan cara-cara yang belum pernah terjadi pada generasi sebelumnya. Kemajuan teknologi, khususnya internet dan media sosial, mengubah waktu, peningkatan kreativitas, pola dan hubungan di tengah-tengah pertumbuhan remaja, mendorong terciptanya budaya kaum muda dengan komunitas budaya yang berbeda pada umumnya. Gereja akan ditinggalkan dan kehilangan peluang jika tidak dapat mengenali dan memahami budaya anak muda; jadi Gereja perlu memasuki kedalam komunitas anak muda sehingga kaum muda dapat melayani secara kontekstual, sesuai dengan kebenaran Firman Tuhan dan tepat sasaran, sehingga kaum muda memiliki spiritualitas yang baik.
\end{abstract}

Kata kunci: Kebudayaan, kaum muda, komunitas, spiritualitas.

\footnotetext{
${ }^{1}$ Penulis adalah Dosen dan Kaprodi Sekolah Tinggi Theologia Nazarene Indonesia. Terlibat dalam Pelayanan Pengembangan Anak (Holistic Child Development) dan Pelayanan Lintas Budaya.
} 


\section{Pendahuluan}

Kaum muda merupakan generasi yang memiliki kekhasan dan keunikan tersendiri, selalu dinamis dan memiliki kebiasan atau budaya yang berbeda, bahkan belum pernah terjadi pada generasi sebelumnya. Pada zaman sekarang (baca: "Zaman Now") dengan kemajuan teknologi dan kemudahan serta kebebasan akses ke dalam dunia maya atau dunia digital, membentuk pola pikir, tingkah laku dan budaya yang sangat berbeda dengan anak-anak muda sepuluh bahkan lima tahun yang lalu

Dengan budaya kaum muda yang unik dan cepat berubah selaras dengan perkembangannya, pastilah ada sisi positif dan negatifnya. Kecepatan dunia internet sangat mempengaruhi kehidupan anak muda, yang acapkali orang tua, gereja atau para pemimpin kaum muda jauh tertinggal di belakang dan tidak bisa mengimbangi budaya anak muda yang datang secepat kilat, berubah secepat angin dan berganti seperti siang dan malam.

Tentu ini sebuah realita yang harus disikapi oleh semua pihak termasuk gereja, agar bisa mendampingi kaum muda sehingga mereka tidak menjadi generasi yang terhilang, tetapi justru menjadi kaum muda yang patut diteladani oleh orang-orang muda lain yang sedang larut dalam budaya baru di era digital ini. Jika gereja ingin melayani kaum muda sesuai dengan konteks dan budaya mereka dengan sepenuh hati, maka gereja perlu mengenali dan memahami budaya kaum muda tersebut agar bisa melayani kaum muda dan memenangkan mereka bagi Tuhan.

\section{Tantangan Pelayanan Kaum Muda}

Perkembangan zaman selalu membawa dampak perubahan-perubahan dalam segala bidang, salah satunya adalah perkembangan dan berubahnya sistem kehidupan dalam penggunaan 
teknologi sebagai pendukung kehidupan umat manusia. Pada zaman purba, manusia menggunakan alat-alat sederhana untuk menunjang kehidupannya, namun semakin hari manusia mengembangkan alat-alat tersebut dan semakin baik, bahkan dalam dunia sekarang bukan hanya baik tetapi "canggih;" demikian juga berkenaan dengan perubahan teknologi yang dahulu masih manual sekarang masuk ke dalam masa digital.

Digital berasal dari kata Digitus, dalam bahasa Yunani berarti jari jemari. Apabila kita hitung jari jemari orang dewasa, maka berjumlah sepuluh (10). Nilai sepuluh tersebut terdiri dari 2 radix, yaitu 1 dan 0, oleh karena itu Digital merupakan penggambaran dari suatu keadaan bilangan yang terdiri dari angka 0 dan 1 atau off dan on (bilangan biner). ${ }^{2}$

Revolusi Digital adalah perubahan dari teknologi mekanik dan elektronik analog ke teknologi digital yang telah terjadi sejak tahun 1980 dan berlanjut sampai hari ini. Revolusi ini dipicu oleh sebuah generasi remaja yang lahir pada tahun 80-an. Revolusi digital ini telah mengubah cara pandang seseorang dalam menjalani kehidupan yang sangat canggih saat ini. Sebuah teknologi yang membuat perubahan besar kepada seluruh dunia, dari mulai membantu mempermudah segala urusan sampai membuat masalah karena tidak bisa menggunakan fasilitas digital yang semakin canggih ini dengan baik dan benar.

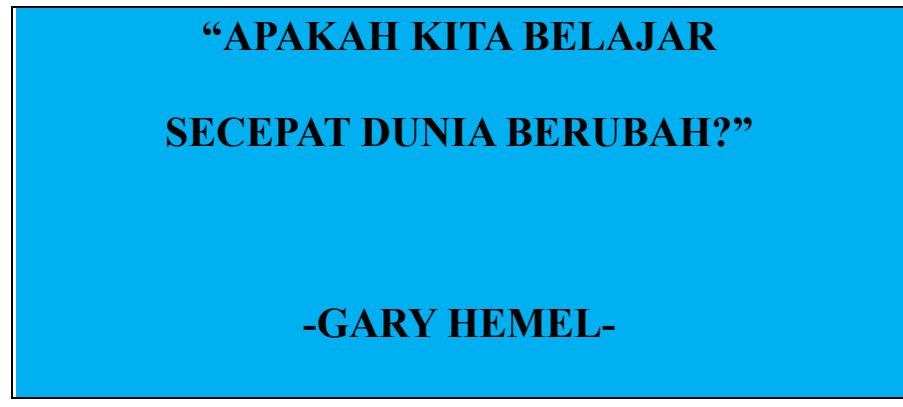

Gambar 1

Quote Gary Hemel 327.

${ }^{2}$ Kamus Besar Bahasa Indonesia (edisi ke empat), (Jakarta: Departemen Pendidikan Nasional), 2008, hal. 
Gary Hemel, ${ }^{3}$ bertanya: “Apakah kita belajar secepat dunia berubah?” Dalam kenyataanya kita selalu ketinggalan satu langkah atau beberapa langkah di belakang, dan kita terus harus belajar dan mengikuti perkembangan dan perubahan dunia ini jika tidak ingin ketinggalan jaman. Dan tantangan perubahan-perubahan di dunia ini juga membawa dampak dalam pelayanan kaum muda di gereja, sebab merekalah yang sedang dalam dunia pembelajaran dan orang yang dekat dengan penggunaan berbagai teknologi, terutama teknologi informasi yang sangat cepat masuk dan tidak bisa dibendung; dan akhirnya membentuk dunia baru bagi kalangan kaum muda. Lalu apa yang harus kita mengerti seputar kaum muda?

\section{Budaya Kaum Muda}

Kaum muda adalah orang yang sangat dekat dengan dunia hiburan (industri hiburan) kita familier dengan kata "entertaiment"; dalam pengamatan kita bisa melihat bahwa kaum muda banyak menghabiskan waktunya untuk menikmati hiburan seperti: mendengarkan musik, main game, menonton film, dan yang lainnya. Dunia hiburan dan perangkatnya memberikan kemudahan bagi kaum muda untuk menikamatinya, bahkan hanya dengan satu kali tekan tombol atau satu sentuhan, penulis sudah bisa mengakses dan menikmati layanan berbagai macam hiburan yang memanjakan penulis. Kehidupan dalam balutan industri hiburan dekade ini telah membentuk pola kehidupan kaum muda dan telah menjadi "budaya," dan bisa terjadi 3 sampai 5 tahun kedepan, pola kehidupan kaum muda akan berubah sesuai dengan perubahan-perubahan yang terjadi dan itu akan membentuk dunia baru (budaya) dalam kehidupan kaum muda.

${ }^{3}$ DR.Gary Hemel adalah pakar manajemen dari Amerika Serikat. Bersama C.K Prahalad di kenal sebagai pencetus konsep "kopetensi inti" salah satu pemikir bisnis yang berpengaruh di dunia. 
Jadi untuk mendampingi dan melayani kaum muda, orang-orang tua harus mengerti "budaya" kaum muda yang ada sekarang. Tidak bisa orang-orang tua berpikir sebagai senior atau orang yang lebih tua mengatakan: Zaman saya dulu tidak begini....; Wah anak muda zaman sekarang memang susah diatur...; Anak muda sekarang susah di kasih tahu, tak mau mendengarkan orang tua...; dan lain-lain ungkapan yang sering didengar dari masyarakat menyikapi perilaku kaum muda sekarang.

Bahkan walaupun dalam kurun waktu satu zaman, kita masih harus memilah-milah di mana kaum muda yang akan dilayani berada. Kaum muda di Jakarta akan berbeda dengan kaum muda di Bandung; akan sangat berbeda dengan budaya kaum muda di daerah dan kota kecil lainnya, karena memang secara global kaum muda semua dipengaruhi oleh teknologi informasi melalui media sosial yang sama, namun tipologi budaya adat setempat masih ikut mempengaruhi dan membentuk pola budaya kaum muda.

Masuk dalam budaya kaum muda, adalah cara yang baik dan efektif untuk mengetahui sesungguhnya kaum muda sekarang ini; apa kebutuhan mereka, dari sisi mana bisa mendekati mereka, bahkan lebih jauh dengan apa kaum muda bisa dipengaruhi dan arahkan. Kalau orangorang tua berusaha membawa kaum muda ke dalam dunia orang tua atau dewasa, sebagai orang tua yang sudah merencanakan sebuah kegagalan sejak awal. Pertama kaum muda tidak akan familiar hidup dalam budaya di luar budaya mereka, yang kedua kaum muda yang melayani sebagai orang tua akan penat dan frustasi karena selalu tidak ada titik temu dalam berkomunikasi karena beda budaya. Jadi untuk menyamakan persepsi satu budaya, sebagai orang yang lebih tua atau senior yang harus melebur ke dalam budaya kaum muda, karena kita yang sedang berusaha menolong, mendampingi dan mengarahkan kaum muda. Di sisi pandangan kaum muda, akan mendapat tempat di hati mereka karena sebagai orang tua yang hidup dan mengerti budaya kaum 
muda, bahkan akan dijadikan mentor dalam dunia mereka; kalau ini terjadi, untuk memenangkan kaum muda pintunya sudah terbuka lebar.

\section{Budaya Intertainent}

Intertaiment memiliki arti: hiburan atau pertunjukan; biasanya dihubungkan dengan dunia "selebriti" atau artis yang berkenaan dengan penampilan panggung para artis; dan juga sekarang merambah ke dunia yang mengelola acara-acara resmi dengan hiburan dan tata panggung seperti untuk acara pernikahan. Tujuannya adalah menunjukkan atau menampilkan sesuatu yang "wah", yang membuat orang yang melihat terkesima atau berdecak kagum.

Sekarang ini intertaiment sudah menjadi bagian hidup bagi sebagian besar orang, terutama anak muda yang sangat dekat dengan dunia glamour, karena era digital yang memudahkan setiap detik segala informasi dan iklan kemewahan di suguhkan di hadapan kaum muda. Bila informasi dan asupan dunia hiburan yang menjadi menu kaum muda setiap waktu, hari, jam, menit bahkan detik; maka prilaku dan cara berfikir akan mengikuti apa yang menjadi sumber pengaruh mereka. Walaupun sesungguhnya dunia hiburan bukan hanya milik kaum muda semata, tetapi merupakan kebutuhan semua orang di semua tingkatan usia.

Melalui dunia intertaimen inilah kaum muda belajar dan menempatkan diri sebagai bagian komunitasnya; mereka berdandan gaya tertentu, memakai barang merk tertentu, dan hal-hal yang lain agar mereka bisa diterima menjadi bagian dari komunitas tertentu. Dalam sebuah bukunya Santrock menegaskan bahwa selain fungsi dan kegunaan media untuk memberikan hiburan, 
informasi dan sensasi, media juga memberikan model gender bagaimana seharusnya bersikap dan memiliki perasaan terhubung dengan jaringan teman sebaya. ${ }^{4}$

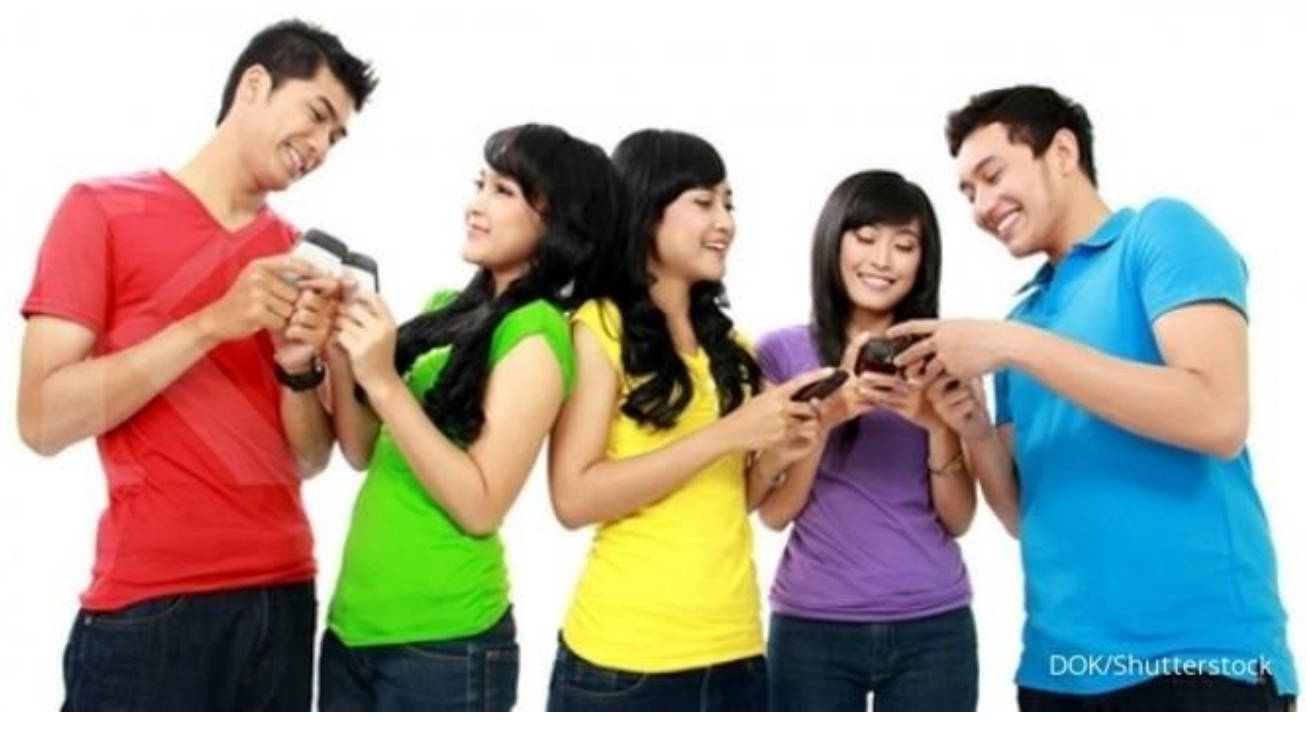

Gambar 2

Pemuda-Pemudi Milenial

Kaum muda telah hidup bergelimang dengan hiburan, berbagai informasi dan stimulus yang hampir semuanya bersifat kesenangan. Kaum muda sangat dekat dengan teknologi media yang senantiasa menjadi bagian hidup mereka kemanapun mereka berada. Bahkan dalam dunia pendidikan sekarang ini; unsur-unsur kesenangan melalui media diyakini akan meningkatkan daya tangkap anak didik dalam belajar; tidak heran jika sekarang ini ruang kelas atau kuliah harus ada sarana multi media; untuk menayangkan materi pembelajaran baik yang bersifat audio maupun video, juga dengan ragam media dan program yang sangat menyenangkan.

Lalu bagaimana komunitas baik itu gereja dan orang tua bisa melayani kaum muda yang hidup beorientasi dengan hiburan? Banyak anak-anak muda yang lari dari komunitas

\footnotetext{
${ }^{4}$ John Santrock, Perkembangan Remaja, (Jakarta: Erlangga), 2003, hal. 315.
} 
persekutuannya/gereja karena merasa di tempat itu sudah tidak menarik lagi, tidak menyenangkan lagi, sudah ketinggalan dengan kelompok lain. Dan fenomena ini perlu kita sikapi dengan bijak; jika semua orang sebagai pelayan atau pembina kaum muda melakukan segala usaha untuk membuat remaja/kaum muda untuk tetap bertahan dan tidak meninggalkan komunitasnya di gereja dengan membuat aktivitas-aktivitas yang menyenangkan seperti, kegiatan olahraga, permainan, nonton bareng, konser musik, dan hal-hal lain yang memasukkan unsur menghibur dalam ibadah dengan tata panggung yang baik, dekorasi, lampu sorot yang berwarna-warni; maka sesungguhnya kegiatan pelayanan untuk kaum muda tidak ada bedanya dengan komunitas-komunitas di luar gereja, dimana ibadah akan menjadi mirip bahkan sama dengan sebuah pentas seni atau konser musik.

Bahaya dari pelayanan kaum muda yang beorientasi pada "upaya menghibur". Pelayanan kaum muda yang aktivitasnya beorientasi untuk membuat senang pemudanya, akan menghasilkan kaum muda yang sulit untuk memiliki komitmen yang panjang, karena ketahanan mereka untuk berkomitmen kepada sesuatu hanya sebatas pada masa mereka senang. ${ }^{5}$ Tidah heran banyak kaum muda yang sulit untuk berkomitmen dalam mengambil bagian tugas pelayanan tertentu, karena komitmennya hanya sebatas di mana mereka mendapat kesenangan ketika mengerjakannya. Untuk itu sebagai orang-orang yang melayani kaum muda harus jeli melihat fenomena ini, ketika melayani kaum muda berdasar orientasi menyenangkan mereka kita sudah mengerti kira-kira produk atau kualitas kaum muda akan seperti apa.

${ }_{5}$ Brian Cosby, Giving Up Gimmicks: Reclaiming Youth Ministry from Entertaiment Culture, (Phillipsburg, New Jersey, P\& R), 2012, hal. 80-83. 


\section{Seni dan Spiritualitas}

Seni dan spiritualitas adalah dua hal yang sangat dekat karena seni menjadi ekspresi mendalam di kehidupan spiritualitas Kristen, baik secara individual maupun komunal. Seni telah berabad-abad dipakai untuk mengungkapkan kebenaran Firman Tuhan yang dapat diterima secara mendalam oleh umat. Dalam pelayanan kaum muda seni juga menempati posisi yang penting. Seni dipakai sebagai sarana pembelajaran, sarana pengayaan, dan ekspresi keindahan Tuhan; namun demikian jika seni tersebut tidak dikelola dengan baik dan benar, malah bisa menjauhkan esensi tentang kebenaran Firman Tuhan dalam kehidupan kaum muda, karena hanya memahami bentuk-bentuk seni itu sendiri dan berhenti di situ saja; padahal seni seharusnya menjadi ekspresi yang dipakai dalam pembentukan spiritualitas kaum muda.

Dalam hal ini, sudah selayaknya jika para pelayan kaum muda dibekali dengan pengetahuan dan ketrampilan akan "ilmu liturgika," yang akan menolong memahami bagaimana menggunakan seni dalam pelayanan gerejawi. Bagaimana kita mengerti dengan baik hal Lagu dan Musik dalam pelayanan Gereja, Gambar-gambar visualisasi dalam pelayanan, Drama dan Tarian dalam Pelayanan, dan lain sebagainya. Dengan demikian ketika kita mempersiapkan materi dan usaha dalam membuat kurikulum pelayanan anak muda kita bisa membuat panduan agar pelayanan-pelayanan yang bersentuhan dengan hal-hal seni di atas bisa membawa anak-anak muda lebih mengerti Firman Tuhan, bukan hanya untuk bersenang-senang menjadi penikmat seni itu sendiri, tetapi akan membawa anak muda lebih mengagumi karya Tuhan yang akhirnya membangun pengertian bahwa Tuhan adalah sumber segalanya, bagi kaum muda itu juga tentunya.

Dalam hal pelayanan/liturgika sering kali gereja-gereja tidak punya rencana yang tetap untuk membina dan mempersiapkan para pelayan dengan latihan atau pendidikan secara berkala 
dan memadai; para pelayan kaum muda hanya belajar dengan cara melihat dan mengikuti para seniornya atau kakak-kakak pelayan yang terdahulu. Atau juga karena ditambahkan ke dalam satu tim pelayanan yang sudah ada, sehingga mengikuti pola tim yang ada; hanya itu bekal yang di dapat untuk ambil bagian dalam melayani. Sehingga sangat perlu gereja memikirkan hal ini, yaitu membuat pelatihan berkala bagi para pelayan kaum muda sesuai dengan perkembangan dan kebutuhan jaman.

\section{Pemimpin (Gembala) Kaum Muda}

Dalam hal mengendorong, membangun dan mengembangkan kehidupan kaum muda yang baik di dalam gereja; tentu tidak bisa dipisahkan dengan peran para pemimpin kaum muda di gereja itu sendiri. Sering terjadi gereja hanya menuding bahwa anak-anak muda berlaku kurang baik, tidak bisa di atur dan lain sebagainya, namun dalam sisi yang lain gereja sendiri tidak melakukan apa-apa untuk merubah atau melakukan pembinaan.

Ada beberapa gereja yang mengkhususkan membina kaum muda dan menempatkan pelayan khusus (gembala kaum muda), bukan hanya membiarkan kaum muda mengatur atau mengurusi diri sendiri (yang umum ada pengurus kaum muda) yang dipilih dari, oleh dan untuk kaum muda itu sendiri; namun gereja menempatkan seorang gembala bahkan pendeta khusus yang menangani dan membina kaum muda. Tentu gereja tidak bisa hanya menempatkan gembala kaum muda secara sepihak karena ada kepentingan gereja untuk membina kaum muda, tetapi harus juga memikirkan apakah gembala kaum muda itu bisa diterima di kalangan kaum muda itu sendiri. Untuk itu ada hal-hal yang harus dipikirkan oleh gereja dalam memilih atau menempatkan seorang gembala kaum muda. 
Figur

Kaum muda sangat dipengaruhi oleh sesosok figur atau tokoh yang menjadi idola mereka, kaum muda selalu mengikuti apapun yang berbau "kekinian," semua hal yang baru menjadi konsumsi kaum muda, mulai dari musik, lagu, artis, mode, gaya hidup, dan lain sebagainya. Jika seseorang (kaum muda) sudah mengidolakan tokoh tertentu (misal penyanyi) maka semua apa yang dilakukan apa yang dipakai, gaya bicara dan tingkah laku sang idola di tiru. Maka penting untuk menempatkan seorang gembala kaum muda bagi mereka adalah seseorang yang menjadi teladan, seseorang yang benar-benar bisa mempengaruhi kehidupan kaum muda, tidak hanya sekedar jabatan semata. Mungkin akan dipilih pemimpin atau gembala kaum muda itu sesosok yang usianya tidak berpaut jauh dengan kaum muda yang dilayani bahkan bisa sebaya; hal yang penting dalam memimpin kaum muda adalah dengan teladan; seperti nasehat Paulus kepada Timotius: Jangan seorangpun menganggap engkau rendah karena engkau muda. Jadilah teladan bagi orang-orang percaya, dalam perkataanmu, dalam tingkah lakumu, dalam kasihmu, dalam kesetiaanmu dan dalam kesucianmu. (1 Timotius 4:12)

Kaum muda akan melihat apa yang dilakukan pemimpin bukan mendengar apa yang dikatakan oleh para pemimpin mereka; itu benar terjadi juga di dalam keluarga; anak-anak susah diatur karena banyak orang tua yang memberi nasehat tapi tidak memberi contoh dan teladan yang baik, sehingga anak-anak tidak mau mendengarkan nasehat orang tua mereka.

\section{Sentrifugal}


Ada istilah dalam ilmu gaya (gerak) sebuah benda yaitu gaya Sentripetal dan gaya Sentrifugal, yang kemudian hari dipakai juga sebagai istilah dan gaya Pelayanan Misi dalam Ilmu Misiologi. Dalam ilmu gerak sebuah benda teori mengatakan: Ketika sebuah benda melakukan gerak melingkar, pada benda tersebut bekerja gaya sentripetal yang arahnya menuju pusat lingkaran, apabila terdapat gaya sentrifugal yang arahnya menjauhi pusat, maka akan terdapat gaya total yang menyebabkan benda bergerak sepanjang garis lurus.

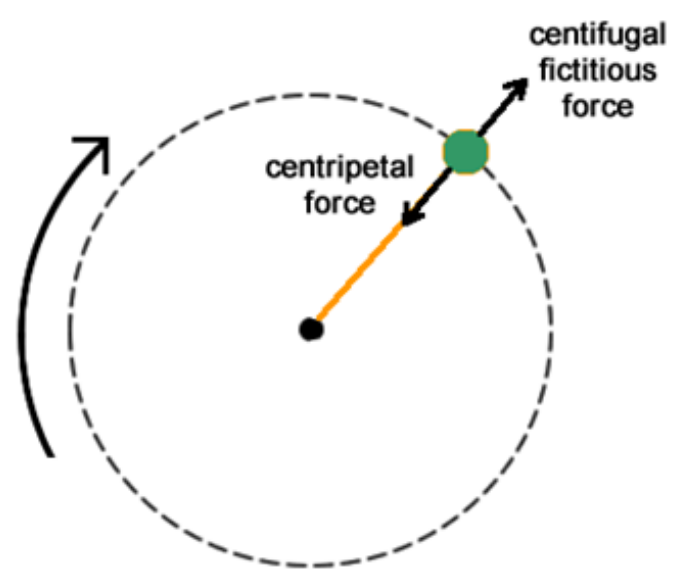

Gambar 3 Centripetal Dan Centrifugal

Dalam dunia misologi istilah ini juga dipakai untuk menggambarkan gaya misi di Perjanjian Lama dan Perjanjian Baru. Dalam dunia Perjanjian Lama, Misi Allah untuk dunia ini disebut gaya Sentripetal, dimana Allah memanggil semua bangsa melalui orang-orang atau bangsa pilihan (Israel) untuk datang kepada Allah dan menjadi umat Tuhan (dari luar dipanggil masuk ke dalam); sedangkan dalam dunia Perjanjian Baru, Misi Allah bersifat Sentrifugal; dimana Allah sendiri dalam diri Tuhan Yesus meninggalkan sorga, keluar mencari dan menemukan manusia dari segala suku dan bangsa untuk menjadi umat Tuhan (dari dalam ke luar). 


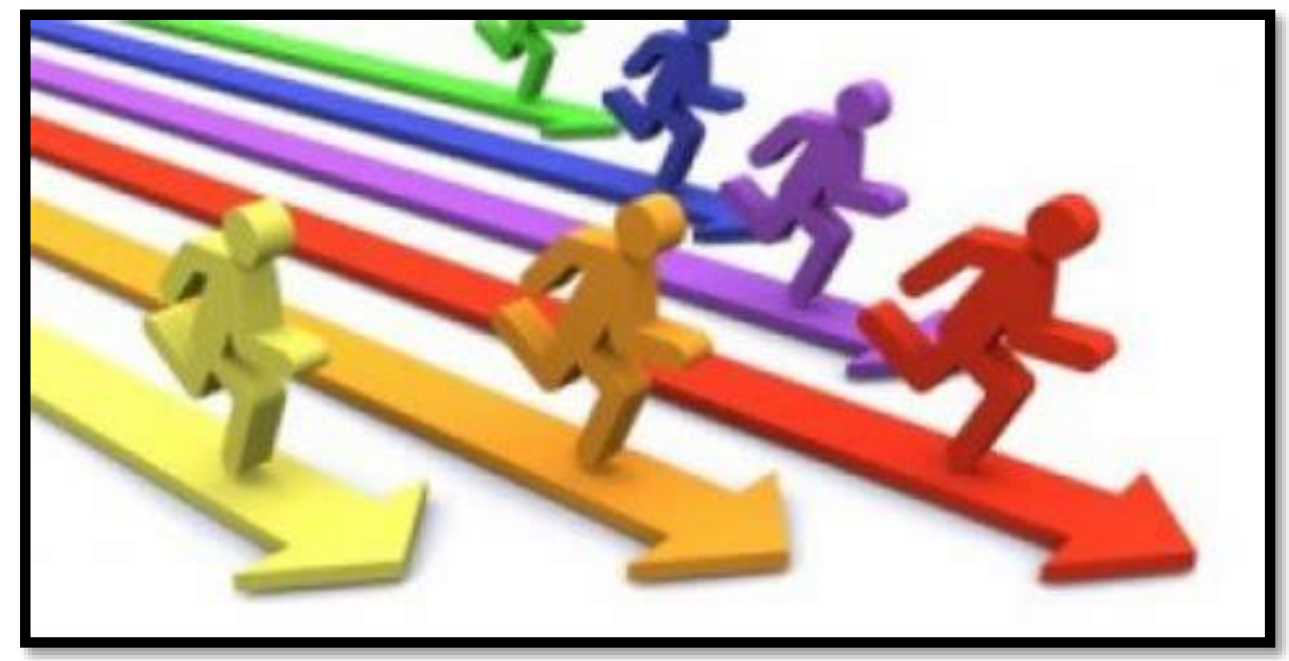

Gambar 4

Fokus Kepada Pemimpin (Siapa Pemimpin)

Dalam realita kehidupan anak muda saat ini tidak bisa seperti gaya memimpin tahun 80an, dimana gereja menunggu kaum muda untuk datang dan dilayani, kalau tidak datang dibiarkan saja atau hanya sebagai bahan pembicaraan saja. Jaman sekarang anak muda ada di tempat-tempat di luar gereja dengan komunitasnya, sebagai pemimpin kaum muda, gereja harus meninggalkan kursi tempat duduk dan keluar untuk bertemu dengan mereka di tempat-tempat yang mungkin aneh dan tersembunyi dari gereja, untuk menggembalakan dan menjangkau kaum muda. Mengapa harus menunggu mendoakan mereka di gereja, memberikan siraman rohani di gereja? Bagaimana kalau kaum muda tersebut tidak lagi mau ke gereja? Sikap keredahan hati untuk datang dan berinisiatif bertemu kaum muda di tempatnya merupakan salah satu cara untuk melayani mereka; gereja harus masuk ke dalam dunia mereka yaitu budaya kaum muda. 


\section{Care}

Dalam kamus bahasa Inggris, ${ }^{6}$ care memiliki arti dan pengertian: perawatan; perhatian; asuhan, perlindungan dan pemeliharaan. Jadi sesungguhnya di dalam melayani kaum muda bukan hanya semata-mata bagaimana memimpin mereka dan memberi ruang untuk mereka berkomunitas di gereja; tetapi seharusnya memberi perhatian yang lebih, dengan cara merawat mereka, memperhatikan mereka, ada pola asuh/pengasuhan; gereja harus memiliki sistem atau regulasi untuk memproteksi kaum muda dari berbagai bahaya dan kejahatan; memelihara mereka sebagai aset yang berharga, karena merekalah generasi penerus gereja yang akan melanjutkan tugas dan tanggung jawab selanjutnya. Bagaimana jadinya kalau gereja dan orang tua tidak memperhatikan kehidupan kaum muda untuk kepentingan masa depan; akan tiba waktunya saat orang tua sudah pensiun dari tugas dan tanggungjawabnya, mungkin baru akan terkejut dan kesulitan karena tidak memiliki penerus generasi yang baik, yang sesuai dengan maksud Gereja (maksud Tuhan).

Kalau boleh penulis ibaratkan gereja sedang menanam pohon buah; tidaklah baik kalau gereja hanya mengambil bibit dan menancapkan di tanah. Jadi, gereja harus mulai dengan mengolah media tanam/tanah lebih dahulu, di gemburkan dengan dicangkul lalu bila ada sesuatu yang tidak baik untuk media tumbuh pohon di buang, mungkin ada batu, kayu, rumput dan hal-hal lain perlu di buang agar tidak mengganggu tumbuh kembang tanaman. Lalu kalau media itu sudah siap, kita tanam bibit pohon buah tersebut; kita siram air, diberi pelindung dari terik matahari karena masih baru dipindahkan dan di tanam supaya tidak layu terkena teriknya sinar matahari. gereja memupuknya secara berkala, menyirami secara rutin, melihat dan meneliti jika ada penyakit

\footnotetext{
${ }^{6}$ John M.Echols dan Hassan Sadhily, Kamus Inggris-Indonesia, (Jakarta: Gramedia), 1996, hal. 98.
} 
atau hal lain yang mengganggu, mungkin juga harus dipagari agar tidak diganggu binatang atau tangan-tangan jahil manusia, dan apapun kita perbuat untuk pohon buah kita bertumbuh dengan baik dan akhirnya bisa menikmati buah yang kita harapkan; kerja keras gereja akan terbayar dengan hasil buah yang baik.

Harusnya sikap gereja dan kita orang tua seperti seorang yang menanam pohon buah di atas; memang perlu kerja keras, perlu tenaga ekstra, perlu biaya, perlu lebih banyak waktu, tetapi kita akan bersyukur jika kita menginvestasikan lebih banyak waktu, tenaga dan biaya untuk pertumbuhan dan perkembangan kaum muda, kita akan menikmati hasilnya dan akan bersyukur karena kaum muda akhirnya menjadi pemuda yang baik.

Mungkin memang era atau setia generasi berbeda, budaya dalam berkomunitas sangat berbeda; orang yang hidup pada era 80an / 90an senang ngobrol bersama sambil menikmati pisang goreng dan secangkir kopi di rumah tetangga, atau kalau anak muda ngobrol duduk-duduk bersama diatas jembatan kampung bergurau sampai larut malam; dunia sekarang ini sangat lain, istilah dahulu kita temu darat (ketemu di udara artinya lewat siaran gelombang radio), sekarang dunia serba online, pertemanan, ngobrol tidak perlu bertemu muka kita bisa ketemu lewat online dari rumah atau tempat masing-masing. Sebagai orang tua atau gereja bagaimana kita bisa masuk ke dalam dunia anak muda sekarang ini untuk ikut terlibat memberi pengaruh dan membentuk pribadi-pribadi kaum muda yang takut Tuhan, apapun eranya apapun medianya, itu harusnya menjadi sikap kita. 


\section{Komunitas}

Komunitas kaum muda gereja masa sekarang ini adalah bagian dari gereja masa kini; sebagai gereja masa kini, komunitas kaum muda kristen, secara naturnya merupakan Redeemed Community, yang juga turut dipanggil untuk menjadi Redemptive Community, terlibat di dalam karya "penebusan" bagi dunia. Ada suatu pekerjaan rumah yang besar bagi komunitas kaum muda Kristen untuk mengerjakan karya penebusan di jaman ini. Apalagi bila melihat kenyataan bahwa kaum muda Kristen hidup di tengah-tengah situasi dan kondisi orang-orang muda pada jaman sekarang ini dengan fenomena seperti: jerat pornografi, masalah seksualitas, isu-isu tentang pacaran dan pernikahan, belenggu narkoba, ikatan dengan kuasa gelap, sepak terjang dalam peintisan karier dan masa depan, juga relasi yang buruk baik dengan diri sendiri, keluarga, maupun teman-teman, dan masih banyak persoalan kaum muda yang lain. ${ }^{7}$
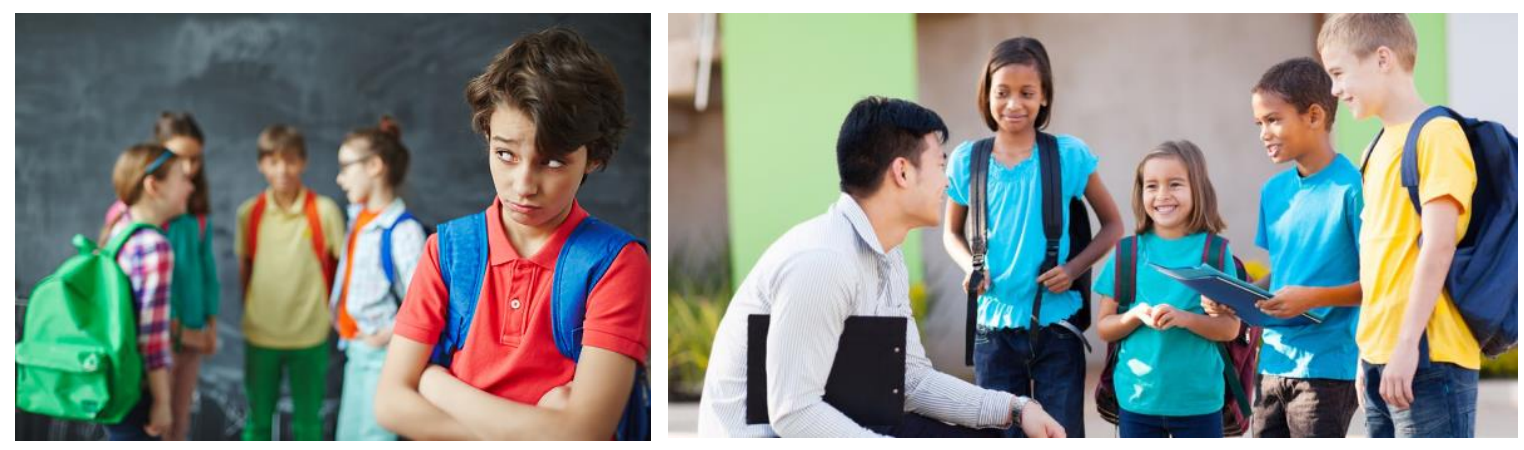

Gambar 5

Pastor Kids (Pendamping Anak-anak)

\footnotetext{
${ }^{7}$ Jurnal Youth Ministry, Vol.2, No. 2, November 2014, hal. 86.
} 
Bagaimana sikap gereja, orang tua terlebih kaum muda Kristen menanggapi fenomena ini? Dalam kenyataannya hal-hal tersebut di atas tidak hanya terjadi pada kaum muda non Kristen, tetapi juga terjadi di antara kaum muda Kristen. Kalau gereja atau orang tua ingin memiliki generasi masa depan yang baik, sudah seharusnya sebagai gereja atau orang tua memikirkan secara serius secara bersama, saling bergandenga tangan untuk melayanui kaum muda dengan baik, yaitu melihat apa yang terjadi di dalam dunia anak muda sekarang ini dan masuk menjadi bagian pembaharu, sehingga kaum muda tertebus dan di tebus untuk hidup di dalam Tuhan.

Jika gereja atau orang tua tidak mengambil komitmen untuk memikirkan kaum muda atau hanya setengah hati saja; maka walaupun kaum muda Kristen berkomunitas di gereja, bisa terjadi pengaruh individualise menyusup masuk ke dalam komunitas Kristen dan menjadikan kelompok atau kounitas itu hanya sebuah kerumunan kaum muda Kristen yang datang dan berkumpul di gereja tanpa pernah menjadi komunitas kaum muda Kristen yang sesungguhnya; yaitu komunitas kaum muda yang mempengaruhi dan menebus sesamanya, membebaskan belenggu persoalan kaum muda untuk "Bertemu Tuhan".

Pikiran lama bahwa orang tualah yang bisa membina, mendidik dan memenangkan kaum muda, pada sekarang ini harus diubah, karena sesungguhnya komunitas teman sebaya lebih efektif mempengaruhi kehidupan anak muda. Sehingga pelayanan kaum muda kini harus dikelola dengan menempatkan pemimpin kaum muda dari antara mereka yang bisa dengan mudahnya masuk di dalam komunitas mereka; tentu bukan berarti orang tua (gereja) melepaskan diri dari tanggung jawab membina kaum muda; tetapi membangun sistem di mana kaum muda memenangkan kaum muda yang lain, itu yang paling efektif. 


\section{Penutup}

Sebagai penutup dalam tulisan ini penulis memberi rangkuan kecil bagaimana sebaiknya komunitas kaum muda Kristen bisa benar-benar menjadi komunitas yang menjadi pengaruh positif bagi kaum muda yang lain.

Pertama, Komunitas harus dibangun dalam keakraban, secara otentik dan transparan.

Keakraban yang dimaksud bukan kedekatan di permukaan, apalagi kepura-puraan, melainkan suatu persekutuan yang akrab, yang sejati, yang asli, di mana setiap orang dapat tampil menjadi dirinya secara transparan, apa adanya. Dengan demikian, di antara anggota komunitas itu terbuka kesempatan untuk saling menajamkan, mengkoreksi dan bertumbuh bersama ke arah yang lebih baik.

Kedua, Komunitas tidak dapat menggantikan tempat Allah.

Satu hal yang harus dipahami bersama dalam membangun komunitas adalah sesempurna apapun sebuah komunitas tidak boleh menggantikan yang esensi dalam kehidupan setiap individu di dalam komunitas adalah adanya "Allah." Pertolongan dan pemulihan di dalam komunitas harus datang dari Tuhan bukan karena komunitas atau gereja; sehingga setiap individu merasakan Allah dalam hidupnya karena berada dalam komuntas tersebut.

Ketiga, Komunitas adalah kebersamaan. 
Komunitas dibangun supaya setiap individu di dalamnya dapat menjalani kehidupan bersama dengan baik. Setiap individu tetap melakukan aktivitas dan pekerjaan masing-masing, tetapi dalam semuanya itu, mereka memiliki kesadaran bahwa ada saudara-saudara yang berjalan bersamasama mereka, yang ada dan tersedia untuk mereka, yang siap membantu dan mengangkat mereka bila jatuh, dan menolong mereka, juga mendorong mereka untuk menjadi lebih baik, (berdoa, bermain, makan, beribadah, berbagi, dan yang lainnya).

Keempat, Komunitas tidak terjadi secara instan.

Membangun komunitas tidak mungkin terjadi dalam satu hari, satu waktu atau pada satu tempat tertentu saja, semua itu membutuhkan proses dan berbagai konteks pengalaman hidup. Jadi memang perlu sebuah keputusan, tekat dan komitmen untuk bisa membangun komunitas; terlebih lagi jika memiliki maksud bahwa komunitas tersebut untuk membangun sesamanya untuk lebih baik. Harus ada perjuangan dan pengorbanan dalam segala hal, baik waktu, tenaga dan dana, dan hal lain.

Kelima, Komunitas adalah tempat yang aman.

Bagian terakhir adalah bagaimana bukan hanya citra tapi benar-benar terbukti bahwa komunitas yang kita bangun itu adalah tempat yang aman bagi setiap individu yang berada di dalamnya. Komunitas (apalagi komunitas kaum muda Kristen/gereja) harus merupakan sebuah tempat yang aman dan dapat dipercaya, di kebutuhan (terutama kebutuhan hati dan jiwa) dapat tersentuh di sini. Untuk itu setiap individu di dalamnya utamanya para pengurus dan pembina (gereja) benar-benar memiliki tanggung jawab untuk siapa saja yang ada di dalm komunitas merasa terlindungi dan aman dari hal-hal jahat dari luar komunitas tapi juga dari dalam komunitas itu sendiri. 
Pada akhirnya komunitas yang baik yang bisa menjadi sebuah budaya (life style) kaum muda yang baik akan menjadi sumber mata air yang terpancar, di mana setiap individu yang sedang mengalami dahaga dalam pengembaraan hidup dan pergumulan yang sedang dihadapi, dapat menemukan kelegaan dan kesegaran kembali untuk melanjutkan langkah kehidupan ke depan dengan segala berkat dan damai sejahtera dari Tuhan.

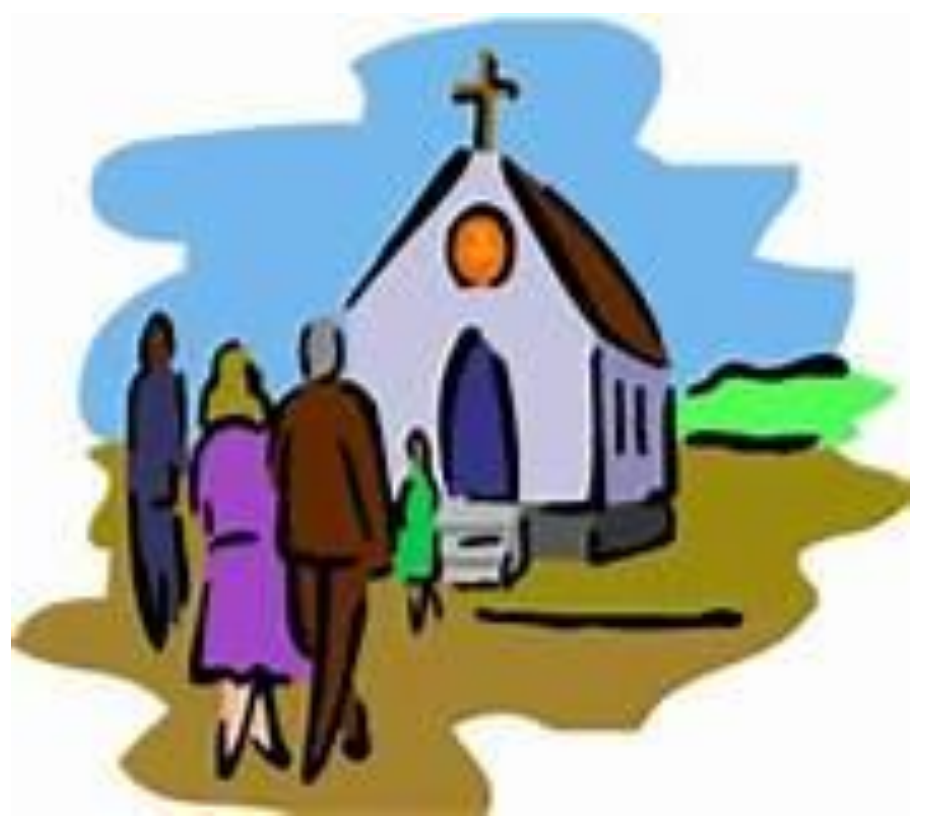

Gambar 6

Keluarga Dalam Komunitas Religi 


\section{DAFTAR PUSTAKA}

Alkitab, Jakarta: Lembaga Alkitab Indonesia, 2007.

Cosby, Brian. Giving Up Gimmicks: Reclaiming Youth Ministry from Entertaiment Culture, Phillipsburg, New Jersey, P\& R, 2012.

Echols. John M. dan Hassan Sadhily, Kamus Inggris-Indonesia, Jakarta: Gramedia, 1996.

Jurnal Youth Ministry, Vol.2, No. 2, November 2014.

Kamus Besar Bahasa Indonesia (edisi ke empat), Jakarta: Departemen Pendidikan Nasional, 2008

Santrock, John. Perkembangan Remaja, Jakarta: Erlangga, 2003. 
46| Jurnal Teologi SANCTUM DOMINE 